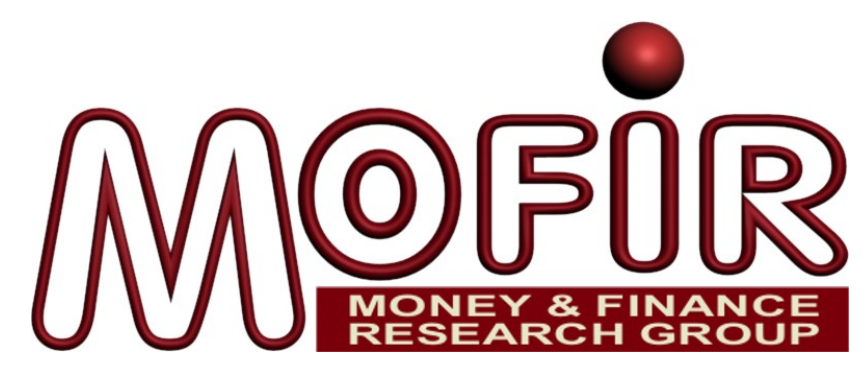

\title{
The Effects of Financial and Real Wealth on Consumption: \\ New Evidence from OECD Countries
}

\author{
RicCARdo De Bonis \\ Bank of Italy \\ $M o F_{I} R$ \\ Andrea Silvestrini \\ Bank of Italy
}

MoFiR working paper $n^{\circ} 38$

April 2010 


\title{
The Effects of Financial and Real Wealth on Consumption: New Evidence from OECD Countries
}

\author{
Riccardo De Bonis ${ }^{1}$ and Andrea Silvestrini ${ }^{2}$
}

\begin{abstract}
In this paper we present new estimates of the effect of household financial and real wealth on consumption. The analysis refers to eleven OECD countries and takes into account the years from 1997 to 2008. Unlike most of the previous literature, we exploit European quarterly harmonized data on household financial assets and liabilities, which have been taken from the flow of funds. We measure not only the effect of total financial wealth on consumption, but we also consider the impact of a subset of those financial assets (i.e., quoted shares, mutual funds, insurance technical reserves) that are more linked to the Stock Exchange. Furthermore, we implement a recent econometric approach that allows for more flexible assumptions in the non-stationary panel framework under consideration. Our main results show that both net financial and real wealth have a positive effect on consumption. Overall, the influence of net financial assets is stronger than that of real assets. Using quoted shares, mutual funds and insurance technical reserves as a measure of financial wealth, we obtain a lower estimate of the marginal propensity to consume, possibly due to the strong concentration of equity instruments in the richest households.
\end{abstract}

Keywords: Household financial and real wealth; Wealth effect; Cointegration JEL classification: C23, E21, E44

\footnotetext{
${ }^{1}$ Bank of Italy, Economics and International Relations.

${ }^{2}$ Bank of Italy, Economics and International Relations.

Corresponding address: Andrea Silvestrini, Bank of Italy, Economics and International Relations, Economic and Financial Statistics Department, Via Nazionale, 91 - 00184 Rome, Italy. E-mail address: <andrea.silvestrini@bancaditalia.it>
} 


\section{Introduction}

The wealth effect is a classic subject of theoretical and empirical macroeconomics. New interest on the topic derived from the behavior of net financial wealth and house prices in the last years. In the US the performance of the Stock Market was exceptional between 1995 and 2000, the years of the Internet bubble. The increase in household financial wealth contributed, together with the decline in interest rates, to the drop of the saving rate and to the support of consumer spending. The burst of the Stock Market bubble started at the beginning of 2000 and led to a decline in share prices until the first months of 2003. Then household consumption was sustained by the increase in the value of houses, which began in the first Nineties but intensified after 2000.

On the contrary, in 2007 the financial turbulence interconnected with the start of falling house prices. According to last statistics, the S\&P Case-Shiller national index of house prices fell by 18.2 percent between March 2008 and March 2009: the fall of nominal prices was bigger than the drop in 1932, at the worst point of the Great Depression. House prices downturns took place in other industrialized countries that had experienced a rapid rise in previous years. In 2008 real house prices decreased in all the main OECD countries. With regard to financial wealth, in many countries the Stock Exchange capitalization was at the beginning of 2009 similar to the 1995 levels, when the great phase of surging prices began.

The goal of this paper is to provide new evidence on the link between financial wealth, real wealth and household consumption in a sample of OECD countries between 1997 and 2008. The novelty of the contribution is to exploit quarterly harmonized statistics on household financial assets, which have been taken from the European flow of funds. This might allow a more precise measurement of household wealth, compared to previous data used in literature. We distinguish among the impact of different components of financial assets (i.e., quoted shares, mutual funds, and insurance technical reserves versus safe assets). We also implement a recent econometric approach that allows for more flexible assumptions in the non-stationary panel framework under consideration: specifically, the pooled estimation of the marginal propensities to consume out of financial and real wealth is carried out by imposing common longrun restrictions, while the short-run parameters, the speed of adjustment and the innovations variances are left unrestricted.

After this introduction, this paper is divided into six sections. Section 2 reviews the literature. Section 3 describes the data properties. Section 4 presents the econometric specification and estimation strategy. Section 5 reports and discusses the empirical results. Section 6 concludes.

\section{A brief review of the literature}

In this Section we summarise the recent literature on the effect of wealth on consumption. We only focus on papers that used aggregated time series, starting with works on single countries and then turning to papers that analysed panel of nations. ${ }^{1}$

\footnotetext{
${ }^{1}$ See Paiella (2004), Altissimo et al. (2005) and ECB (2009) for surveys which include the household-level evidence of wealth effects and Guiso, Paiella and Visco (2005) for an application to the Italian case.
} 


\subsection{Single country studies}

Most of the papers looked at the US experience. In summarising this literature, Poterba (2000) concluded that the marginal propensity to consume out of the Stock Market is between 0.01 and 0.05. More recently, using the American flow of funds, Morris and Palumbo (2001) estimated a consumption response in the range of 3 to 6 cents-to-the dollar, according to particular model specification. Lettau and Ludvingson (2004) distinguished between cycle and trend changes in asset values. Consistent with the previous studies, they found that in the US the marginal impact on consumption of a dollar increased in wealth is about 5 cents. Yet, Lettau and Ludvingson claimed that these estimates are not an appropriate measure of the consumption-wealth link, because only permanent changes in wealth are associated with movements in consumption. Also Lettau and Ludvigson (2001) underlined that large swings in asset values do not need to be associated with large subsequent movements in consumption.

While in the past it was rare to distinguish between real and financial wealth, in recent times this subject received a careful attention. Carrol, Otsuka and Slacalek (2006) estimated that in the US the housing wealth effect is around 9 cents against 4 cents of the Stock Market wealth effect. Also Case, Quigley, and Shiller (2005) found that the housing wealth effect is larger than the Stock Market effect.

Turning to other national cases, Tang (2006) claimed that in Australia a permanent dollar increase in housing wealth led to a six percent rise in consumption, three times the effect of financial wealth. Also in Canada, Pichette and Tremblay (2003) found a significant housing wealth effect, while the Stock Market wealth effect was weaker. On the contrary Bassanetti and Zollino (2007) reached a different result analysing the Italian case: the size of the marginal propensity to consume out of housing wealth was about 1.5-2 cents, against values of 4-6 cents for the propensity to consume out of financial wealth. Studying Germany, Hamburg, Hoffmann and Keller (2008) found that a one euro increased in asset wealth causes an increase in consumption by $4-5$ cents.

\subsection{Panel data studies}

As we anticipated, many authors looked at panel of countries. Working on a group of EU countries, Dreger and Reimers (2006) found a wealth elasticity of consumption in a range of 3-5 percent. Byrne and Davis (2003) analysed the effect of disaggregated financial wealth on consumption functions for G7 countries. They claimed that the indiscriminate aggregation of wealth is inappropriate and found that illiquid assets, such as life insurance instruments and pension funds, have a much stronger effect on consumption than liquid assets, such as deposits. According to Bertaut (2002), consumption responses to a given change in equity prices are comparable in Canada, the UK and the United States, while in European countries the consumption response to changes in wealth remains limited.

More recently, a set of papers tried to measure the effect of both financial and real assets on consumption. Dreger and Reimers (2009) found a consumption elasticity with respect to house prices of 2.5 percent and a consumption elasticity with respect to financial assets of 3 percent. Slacalek (2006), focusing on 16 countries, estimated a long-run marginal propensity to consume out of total wealth averaged across countries of around 5 cents. There was some evidence that the housing wealth effect is smaller than the financial wealth effect, but the opposite was true in the US and the UK, thus confirming the result that Carrol, Otsuka and Slacalek found in the quoted paper on the US. The main explanation of the difference between the countries is that in the UK and the US financial innovation is more sophisticated, letting 
people more easily to take cash out of their homes. For example, mortgage equity withdrawal is more common in the US and the UK than in the euro area. Also Catte et al. (2004) underlined the importance of the structural characteristics of housing and mortgage markets. Studying ten OECD countries, these authors claimed that the marginal propensity to consume out of housing wealth is on average stronger than that out of financial wealth in Australia, Canada, the Netherlands, the UK and the US. These countries have large and efficient mortgage markets, with a specific reference to the opportunities for housing equity withdrawal. Lastly, studying a group of OECD countries, Salotti (2008) found a negative link between wealth and saving, but surprisingly both financial assets and real wealth are not significant in the US in explaining saving.

Labhard, Sterne and Young (2005, LSY thereafter) criticized the literature on the cross-country differences of the marginal propensity to consume out of wealth. According to LSY, these differences are misleading because they are not rooted in explainable structural differences between countries and are, on the contrary, attributable to data deficiencies. LSY confirmed the existence of cross-country differences in the effect of financial wealth on consumption, but argued that these results are non theoretically rational. Using a dynamic panel technique, LSY found that the hypothesis of the long-run marginal propensity to consume out of financial wealth being the same across countries could not be rejected and estimated for this variable a value a little greater than 6 percent.

In their survey of the literature Altissimo et al. (2005) underlined other factors that may influence the consumption-wealth link, such as the length of household planning horizons, the strength of the bequest motive, the expected risk-adjusted rate of return on wealth. Other authors took into account the unemployment rate, interest rates and demographic variables as possible co-determinants of consumption.

\section{$2.3 \quad$ A tentative summary}

It is difficult to summarise the previous literature because it refers to different periods, it employs different estimation techniques and uses different sources for real and financial wealth. However, three issues are common to most of the contributions.

First, a consensus emerged on the need to distinguish between real and financial assets when estimating the wealth effect on consumption: in the past literature aggregate household wealth was often used as determinant of consumption; in other cases the authors concentrated only on financial assets. Second, some recent works found that housing wealth became more important than financial assets in influencing consumption, but this effect is often different if we distinguish between Anglo-Saxon countries, where financial innovation and mortgage equity withdrawal were impetuous, and other European nations, where more traditional banking arrangements prevailed. Third, in the euro area financial assets often do not influence household consumption because financial deepening is smaller than in the United States or the United Kingdom and bank deposits remain important in household portfolio. These issues will be at the core of the empirical analysis presented in Section 5. 


\section{$3 \quad$ Data properties}

\subsection{Data description}

Data were assembled for a period ranging from 1997-Q4 to 2008-Q1, for 11 OECD countries: Austria, Belgium, Finland, France, Germany, Italy, Netherlands, Portugal, Spain, the United Kingdom and the United States. For these countries we collected quarterly data on household consumption expenditure, income, components and total amount of financial wealth, household debt and real wealth. Below we provide a brief description of the dataset.

Our statistics refer to total households. In most of the countries the split between consumer household and producer household (i.e., sole proprietorships) is not available. This is particularly true for financial assets. Quarterly data on household private consumption are taken from the OECD's Quarterly National Accounts database. Quarterly data on personal disposable income are the same employed by Dreger and Reimers (2009), ${ }^{2}$ although we are aware that the use of disposable income may induce a double-counting of the effects of capital income, such as interest and dividend income.

Financial assets include the four main instruments of household financial saving: deposits, securities other than shares, quoted shares and mutual funds units, and insurance technical reserves. Net financial wealth is defined as the difference between total financial assets and financial liabilities (debt). For the eurozone countries we used the harmonized quarterly flow of funds accounts (or financial accounts) produced by the National Central Banks of the euro area and disseminated by the ECB. We also employed flow of funds accounts for the United States and the UK economy. Previous studies often approximated household financial wealth using Stock Exchange capitalization. This choice has two shortcomings. First, only a fraction of the firms quoted in the Stock Exchange are owned by the households: banks, other intermediaries, industrial firms and the General Government have large stockholdings in quoted corporations. Second, even if the "home bias" is an important issue, households often hold financial instruments in other countries: measuring household financial assets through the national Stock Exchange capitalization does not allow to consider foreign instruments in which households invest their savings. On the contrary, financial accounts include both resident and non residents financial instruments. Of course we are aware of some possible shortcomings of financial accounts. The most important issue is that the estimate of household unquoted shares and other equity is not completely harmonized across countries. For this reason, we do not include unquoted shares in our measure of household financial wealth.

Household real wealth (or household real assets) refers to dwellings; for most of the countries the other components of real wealth are not available. Unless otherwise specified, in the rest of the paper we use the term real wealth to refer to the household dwelling stock. While some countries provide the quarterly value of household dwellings, in most of the cases only annual data are available. For these latter countries, quarterly series are obtained by temporal disaggregation. The source of the real wealth data is mainly the OECD's Households Assets database. Yet, for a number of countries, household real wealth estimates are made available from the National Central Banks. ${ }^{3}$ We underline that the measurement of household real wealth is not harmonized. Due to the fact that data for real wealth are in some cases based on internal calculations and are not officially published, the estimates of the marginal propensity to consume out of real wealth have to be interpreted with some caution.

\footnotetext{
${ }^{2}$ These data are taken from the World Market Monitor provided by Global Insight.

${ }^{3}$ For Portugal, we refer to Cardoso, Farinha and Lameira (2008).
} 
The data used are displayed in Figures A1 and A2, where consumption, financial and real wealth are all expressed as a ratio to income. In particular, Figures A1 and A2 depict three-dimensional graphs of the relation between consumption and wealth, for each country in the panel. Figure A1 shows the plots of Austria, Belgium, Finland, France, Germany, Italy. Figure A2 displays the plots of Netherlands, Portugal, Spain, USA, UK. The x-axis corresponds to net financial to wealth to income ratio, while the $\mathrm{y}$-axis refers to real wealth to income ratio. On the z-axis appear the values of consumption to income ratio. For illustrative purposes, a triangle-based cubic interpolation is used to visualize the shape and the direction of the relationship between the three variables.

As can be remarkably seen in the graphs, for some countries there seems to be a clear positive relation between wealth (real and financial) and consumption: this is the case of Belgium and Italy, for instance, in Figure A1, and United States and United Kingdom, in Figure A2. For other countries, like Germany and Austria, in Figure A1, and Portugal, in Figure A2, it is not possible to draw any kind of conclusion concerning the magnitude and the sign of this relation. Furthermore, some useful information concerning the wealth to income ratios can be inferred from the plots. Let us focus, for instance, on Italy: real wealth to income ratio roughly ranges from 12 to 22 , whether net financial wealth to income ratio is comprised between 8 and 12. Three important remarks are at order. First, as already explained, the stock of net financial wealth is defined as the sum of all financial assets minus liabilities, excluding unquoted shares. Second, by real wealth we mean the value of the stock of dwellings. Third, net financial wealth and real wealth are annual stock values recorded each quarter. Yet, consumption and income are flow variables, available quarterly in our database. This means that, to be meaningful and fully comparable with other empirical studies on the wealth effects (which often present financial assets and real wealth ratios to GDP or disposable income, based on annual data), the previous values have to be divided by four. Therefore, we can deduce by graphical inspection that in Italy, based on the available sample, real wealth to income ratio ranges from 3 to 5.5, whether net financial wealth to income ratio from 2 to 3 . Similar considerations apply to all the other countries. ${ }^{4}$ Clearly, this preliminary graphical inspection needs to be complemented by econometric analysis.

[FIGURES A1 AND A2 ABOUT HERE]

\subsection{Unit root and cointegration tests results}

To identify long-run equilibrium relationships between consumption and real and financial wealth, all expressed as a ratio to income, cointegration tests may only be performed on panels that are known to be non-stationary. In this Subsection we implement panel unit root tests to check whether the variables under study contain zero frequency unit roots in their data generating process. It is widely acknowledged in the literature that panel unit root tests have higher power than unit root tests based on individual time series. Broadly speaking, these tests can be classified into two categories: those that assume the persistence parameters to be common across cross-sections, like the ones by Breitung (2000) and Levin, Lin, and Chu (2002); and those that allow the persistence parameter to vary across the panel's members, as the test suggested by Im, Pesaran and Shin (2003). We shall carry out a complete battery of unit root

\footnotetext{
${ }^{4}$ See Bartiloro, Coletta and De Bonis (2008) for an analysis on the differences of financial and real wealth in the main OECD countries.
} 
tests, with different model specifications. Such a check is important because it is well known that unit root analysis is sensitive to the choice of the model specification.

\section{[TABLE A1 ABOUT HERE]}

Table A1 reports the outcomes of a battery of panel unit root tests for our variables of interest (consumption-income ratio, net financial wealth-income ratio, real wealth-income ratio): Levin, Lin and Chu (2002); Im, Pesaran and Shin (2003); Maddala and Wu (1999); Breitung (2000); Hadri and Larsson (2005). These are commonly used unit root tests. Breitung (2000) is an unbiased version of Levin and Lin (1993) test for the null of non-stationarity (ULL). Levin, Lin and Chu (2002), Im, Pesaran and Shin (2003), Maddala and Wu (1999) and Breitung (2000) test the null of a unit root in the panel. For Hadri and Larsson, conversely, the null hypothesis is that all time series in the panel are stationary. All the technical details are skipped and the interested reader is referred to the references above for additional explanations and a rigorous treatment.

According to LLC, IPS, MW, ULL tests, results imply not rejection of the presence of a unit root for the series in the panel, assuming a constant and a time trend in the test regression. This holds true for consumption over income, net financial wealth over income and real wealth over income, at $5 \%$ significance level. HL test strongly rejects the null hypothesis of stationarity for all the three variables as well. Results are clear-cut and point to non-stationarity, which has to be taken into account at the modeling stage.

To identify stable long-run equilibrium relationships among consumption-income ratio and wealthincome ratios, we turn to the issue of panel cointegration. When the time dimension is relatively large with respect to traditional empirical studies based on panel data, a panel cointegration approach is useful since it allows for a more flexible modeling of heterogeneity within the panel (comparing to simple fixed or random effects models). Moreover, panel cointegration can be implemented with much shorter time spans of data with respect to time series cointegration techniques, and can improve upon small samples limitations of conventional non-stationary methods (Pedroni, 2000). ${ }^{5}$

Like in standard time series, in the panel setting there are different ways to test the null hypothesis of no cointegration. One possibility is to use residual based tests as suggested by Kao (1999), that extends the original Engle-Granger framework to account for panel data. In a nutshell, this approach requires first to estimate by pooled OLS to obtain the residuals, then to implement a pooled Dickey-Fuller regression. This test is based on the idea of deciding whether or not the error process of the estimated regression equation is stationary. If homogeneity and strict exogeneity assumptions hold, this residual based panel test for the null of no cointegration has the same asymptotic distribution as standard panel unit root tests.

Table A2 displays results of the residual panel cointegration test of Kao (1999); the null hypothesis is no cointegration. Specifically, the five test statistics derived by Kao, on the basis of asymptotic results, are presented in the bottom part of the table: in all cases, results imply rejection of the null of no cointegration. The top part of the table reports estimates of the cointegration coefficients using groupmean panel dynamic OLS method. The estimated coefficients are statistically significant and are equal

\footnotetext{
${ }^{5}$ Specifically, when applied to time series, cointegration tests face the very well known problem of lack of power.
} 
to 0.0108 , with quarterly data. This amounts to marginal propensities to consume from financial and real wealth of around 4 cents per euro of additional wealth.

\section{[TABLE A2 ABOUT HERE]}

In summary, empirical evidence suggests that the variables in the panel are non-stationary and cointegrated. This finding is relevant for a proper econometric specification and estimation strategy, as we shall describe in the following Section.

\section{The econometric specification}

Most macroeconomic theories of wealth effects are formulated according to a reduced-form consumption equation of the type

$$
c_{i, t}=\alpha y_{i, t}+\beta^{F W} f w_{i, t}+\beta^{R W} r w_{i, t}+\varepsilon_{i, t}, \quad i=1,2, \ldots, N, \quad t=1,2, \ldots, T,
$$

where $c_{i, t}$ represents private consumption, $f w_{i, t}$ net financial wealth, $r w_{i, t}$ real wealth, $y_{i, t}$ disposable income, all expressed in levels. Equation (1) has been often suggested in the empirical literature. As explained by Altissimo et al. (2005), this equation can be derived in the framework of the Permanent Income Hypothesis (PIH) developed by Friedman (1957), by making proper assumptions about the expected evolution of consumption. At the same time, according to Davidson et al. (1978), (1) is compatible with a steady-state form of the Life Cycle Hypothesis (LCH) exposited by Modigliani (1975).

A ratio specification has been often suggested as a possible transformation ${ }^{6}$ of (1), meaning

$$
\frac{c_{i, t}}{y_{i, t}}=\tilde{\alpha}+\tilde{\beta}^{F W} \frac{f w_{i, t}}{y_{i, t}}+\tilde{\beta}^{R W} \frac{r w_{i, t}}{y_{i, t}}+\varepsilon_{i, t} .
$$

Or, with a different notation,

$$
C_{i, t}=\tilde{\alpha}+\tilde{\beta}^{F W} F W_{i, t}+\tilde{\beta}^{R W} R W_{i, t}+\varepsilon_{i, t}
$$

where $C_{i, t}, W f_{i, t}$ and $W r_{i, t}$ are all expressed as a ratio to income. Note that, in (2), $\tilde{\alpha}, \tilde{\beta}^{F W}, \tilde{\beta}^{R W}$ may be interpreted as marginal propensities to consume out of income, net financial wealth and real wealth, respectively. In this paper we shall focus mainly on specification (2), which has been tested in recent empirical research.

An important issue is to choose the dynamic structure of the relationship between consumption and wealth. For empirical purposes, influential literature estimates autoregressive distributed lag (ARDL) models of consumption on income, introducing lag mechanisms to model the response of consumption to changes in income. Assume, for instance, that

$$
c_{i, t}=\alpha y_{i, t}+\beta w_{i, t}
$$

\footnotetext{
${ }^{6}$ Other transformations are possible, of course. For instance, a log-linear specification was often suggested, if the interest centers on estimating elasticities of consumption with respect to wealth and income.
} 
where $w_{i, t}$ is end of period private total wealth in levels and $\alpha, \beta$ are coefficients to be estimated. Assuming that dividends, interest and capital gains are compounded in income, the law of motion of the stock of wealth can be expressed as

$$
w_{i, t}=w_{i, t-1}+y_{i, t-1}-c_{i, t-1} .
$$

Simply re-arranging the last two equations, we get

$$
c_{i, t}=\alpha y_{i, t}+(\beta-\alpha) y_{i, t-1}+(1-\beta) c_{i, t-1},
$$

which is an ARDL model of consumption on income.

In the paper, the econometric specification in (2) will be given an ARDL structure. The model in (2), indeed, can be easily generalized introducing deterministic terms, an autoregressive lag polynomial for the dependent variable and complicated distributed lag schemes for the explanatory variables:

$$
C_{i, t}=\alpha_{0}+\alpha_{1} t+\sum_{j=1}^{p} \lambda_{i, j} C_{i, t-j}+\sum_{j=0}^{q} \boldsymbol{\beta}_{i, j}^{\prime} \boldsymbol{W}_{i, t-j}+\varepsilon_{i, t},
$$

where $\boldsymbol{\beta}_{i, j}=\left(\tilde{\beta}_{i, j}^{F W}, \tilde{\beta}_{i, j}^{R W}\right)^{\prime}$ and $\boldsymbol{W}_{i, t}=\left(F W_{i, t}, R W_{i, t}\right)^{\prime}$, by definition. If the variables in (3) are integrated of order one, as recognized by Pesaran and Shin (1997), the traditional ARDL approach is no longer applicable (especially when working with large T, large N panels, often termed "data fields"). Since, in Subsection 3.2, variables have been found to be difference stationary and cointegrated, this issue is particularly relevant for the case under study. Therefore, the stationary ARDL model in (3) has to be somehow re-parameterized to take care of the possible long-run relations among the variables.

To this aim, Pesaran, Shin and Smith (1999) show that (3) can be conveniently re-expressed as

$$
\Delta C_{i, t}=\alpha_{0}+\alpha_{1} t+\phi_{i}\left(C_{i, t-1}-\boldsymbol{\theta}_{i}^{\prime} \boldsymbol{W}_{i, t}\right)+\sum_{j=1}^{p-1} \lambda_{i, j}^{*} \Delta C_{i, t-j}+\sum_{j=0}^{q-1} \boldsymbol{\beta}_{i, j}^{*^{\prime}} \Delta \boldsymbol{W}_{i, t-j}+\varepsilon_{i, t},
$$

where $\phi_{i}=-\left(1-\sum_{j=1}^{p} \lambda_{i, j}\right), \boldsymbol{\theta}_{i}=\sum_{j=0}^{q} \boldsymbol{\beta}_{i, j} /\left(1-\sum_{j=1}^{p} \lambda_{i, j}\right), \lambda_{i, j}^{*}=-\sum_{m=j+1}^{p} \lambda_{i, m}, j=1, \ldots, p-1$ and $\boldsymbol{\beta}_{i, j}^{*}=-\sum_{m=j+1}^{q} \boldsymbol{\beta}_{i, m}, j=1, \ldots, q-1$.

Equation (4) represents the error correction re-parameterization of an ARDL model. Since, according to the Granger's representation theorem (Engle and Granger, 1987), there is a clear link between cointegration and error correction mechanism, (4) constitutes the starting point to carry out the estimation of long-run marginal propensity to consume from financial and real wealth, in the framework of dynamic single-equation regressions.

In order to estimate the marginal propensity to consume from financial and real wealth, we apply the mean group estimator by Pesaran and Smith (1995) and the pooled mean group estimator suggested by Pesaran, Shin and Smith (1999). Both estimators have been proposed in the large T, large N panels framework, whenever non-stationarity becomes an issue that can not be neglected. We rely on equation (4), starting from the ratio specification in (2).

We provide some details on the two estimators that we shall use in Section 5. Broadly speaking, the 
mean group estimator is an average of the long-run and short-run coefficients calculated separately for each country $(\forall i=1,2, \ldots, N)$. The panel mean group estimator can be viewed as an intermediate procedure between pooling and averaging group estimates. Specifically, the estimator allows the intercepts, shortrun coefficients and variances to differ across countries, while the long-run parameters are constrained to be identical across groups. This latter assumption is termed by Pesaran, Shin and Smith (1999) "long-run homogeneity" and requires to impose in (4):

$$
\boldsymbol{\theta}_{i}=\boldsymbol{\theta}(\forall i) .
$$

A straightforward extension of the standard pooled mean group estimator, put forward by Pesaran, Shin and Smith (1999), is to let a subset of long-run coefficients to differ across groups, constraining only the remaining long-run parameters to be the same. Assume, in (4), that $\boldsymbol{W}_{i, t}$ can be partitioned in two blocks, i.e.,

$$
\underset{T \times k}{\boldsymbol{W}_{i}}=\left(\begin{array}{cc}
\boldsymbol{W}_{i}^{(1)} & \vdots \\
T \times k_{1} & \boldsymbol{W}_{i}^{(2)} \\
T \times k_{2}
\end{array}\right),
$$

stacking the time series observations for each group (by definition, $k=k_{1}+k_{2}$ ). Let, similarly,

$$
\boldsymbol{\theta}_{i}=\left(\boldsymbol{\theta}_{i}^{(1)} \vdots \boldsymbol{\theta}_{i}^{(2)}\right)
$$

be the long-run coefficients associated to $\boldsymbol{W}_{i}^{(1)}$ and $\boldsymbol{W}_{i}^{(2)}$. In this case, the long-run homogeneity assumption holds only for one of the two subsets of the long-run parameters, for instance

$$
\boldsymbol{\theta}_{i}^{(1)}=\boldsymbol{\theta}^{(1)}(\forall i)
$$

The second block of long-run parameters is not constrained to be identical for all the countries.

In Section 5, we present standard estimates based on the mean group and pooled mean group estimators. Then, we complement our analysis by implementing the extension suggested by Pesaran, Shin and Smith. Specifically, in the estimation of long-run marginal propensities, first we let the marginal propensity to consume out of net financial wealth vary across countries, while we require the marginal propensity to consume out of real wealth to be the same for all the countries. Second, we put the point the other way around, i.e., we let the marginal propensity to consume from real wealth vary across countries, while we require the marginal propensity to consume from net financial wealth to be identical across countries. In this way, country heterogeneity is set up not only for the short-run, but also for the long-run parameters. This, to our knowledge, may be considered as novelty in the wealth effects empirical literature. We discriminate between these two specifications by using standard criteria based on likelihood ratios. Finally, we investigate the role of disaggregate components of total financial assets in the estimation of the wealth effects. 


\section{$5 \quad$ The econometric results}

\subsection{Preliminary evidence based on static pooled estimation}

The first estimates we present are static fixed effects based on the ratio specification in (2). Results are given in Table A3. In the static regression, we include a time trend, which is statistically significant at 5 percent level.

[TABLE A3 ABOUT HERE]

The point estimate of the marginal propensity to consume from real wealth, i.e. MPC (FW), is 0.0071 , while the marginal propensity to consume from real wealth, i.e. MPC (RW), is 0.0008 . These estimates are calculated on the basis of quarterly data, hence they have to be multiplied by four to get annualised values. This means $M P C(F W)=0.0284$ and $M P C(R W)=0.0032$ or, equivalently, 2.84 cents per euro and 0.32 cents per euro, respectively. The estimates are statistically significant working with conventional standard errors, although they are not significant if robust standard errors are used.

Traditional static panel techniques are based on strong homogeneity assumptions among countries. In other words, these models impose a single slope coefficient in the pooled estimation. The assumptions underlying static panel techniques appear to be too stringent in the case under study. Specifically, when the time dimension increases, potential country heterogeneity may be modeled in a richer way than using simple fixed (or random) effects models. This is done in the sequel, by applying pooled mean group and mean group estimators.

\subsection{Benchmark results: pooled mean group and mean group estimators}

Hereafter, we consider the pooled mean group and mean group estimators, within an autoregressive distributed lag framework. The model is (2), in ARDL form as in (3), and re-parameterized introducing an error correction mechanism as in (4), is the starting point to perform mean group and pooled mean group estimation. For each country, the lag order of the ARDL model is chosen by applying the Schwarz Bayesian information criterion. Table A4 gives the selected lag orders.

[TABLE A4 ABOUT HERE]

The most commonly chosen representation is an $\operatorname{ARDL}(1,1,0)$, which in our framework reads as

$$
C_{i, t}=\alpha_{0}+\alpha_{1} t+\lambda_{i, 1} C_{i, t-1}+\tilde{\beta}_{i, 0}^{F W} F W_{i, t}+\tilde{\beta}_{i, 1}^{F W} F W_{i, t-1}+\tilde{\beta}_{i, 0}^{R W} R W_{i, t}+\varepsilon_{i, t}, \quad i=1,2, \ldots, N
$$

that is, consumption over income is lagged once, net financial wealth over income is lagged once and only contemporaneous terms of real wealth over income are included.

Once the lag orders of the ARDL models have been selected for each country, the pooled mean group (PMG) estimator is used to obtain estimates of the marginal propensity to consume out of financial and 
real wealth. ${ }^{7}$ Estimation is conducted by concentrated maximum likelihood, assuming Gaussianity of the innovations of the model in (4) with $\boldsymbol{\theta}_{i}=\boldsymbol{\theta} \quad(\forall i)$. Table A5 presents the results of standard PMG estimation, when both the long-run coefficients (propensity to consume from financial and real wealth) are constrained to be identical across countries.

\section{[TABLE A5 ABOUT HERE]}

Formally, the homogeneity assumption in (5) holds. The variances and the short-run parameters are unconstrained, as usual. Interestingly, both the marginal propensities are significant and positive, as expected. With quarterly data, the marginal propensity to consume out of real wealth is equal to 0.006 , and the marginal propensity to consume out of net financial wealth is 0.011. On an annual basis, this corresponds to 2.4 cents per euro and 4.4 cents per euro, respectively. Therefore, the marginal propensity to consume out of net financial wealth is found to be nearly two times the marginal propensity to consume out of real wealth. This holds true, of course, by assuming long-run homogeneity of the parameters across countries. Concerning the speed of adjustment parameters, they are negative, and significant, in all countries except Portugal (in this country the estimate is positive but not significantly different from zero). Overall, the fit is fairly good, excluding Netherlands, Portugal and Spain. For this three countries, there is some evidence of misspecification.

\section{[TABLE A6 ABOUT HERE]}

As an alternative to PMG, the mean group (MG) approach is based on averages of the group-specific parameters, after separate regressions have been estimated for each country. Table A6 presents estimates of the unconstrained long-run and short-run parameters obtained by averaging the corresponding parameters calculated for each country. Also in this case, the point estimates of the marginal propensities to consume are significant and positive, as expected ( 0.0013 for real wealth and 0.0117 for net financial wealth, i.e., 0.5 cents per euro and 4.7 cents per euro on an annual basis, respectively). The speed of adjustment is significant and negative (-0.3951).

As pointed out by Pesaran, Shin and Smith (1999), while the MG estimator requires to run N separate regressions and average the parameters of interest, the PMG estimator is obtained by pooling the data and by constraining some parameters (e.g. variances, long-run coefficients) to be identical across groups. Therefore, under slope homogeneity, it is expected that this latter (PMG) is more efficient than the former (MG), which is based on averages of parameters estimated for each country. Based on this, it is possible to test the long-run homogeneity hypothesis. Details are in Pesaran, Shin and Smith (1999). Running an Hausman test between the mean group (Table A6) and the pooled mean group (Table A5) estimates, we get a value of 0.49. Under the null hypothesis of long-run homogeneity, the test statistic is asymptotically distributed as a chi-square with as many degrees of freedom $\operatorname{as} \operatorname{dim}(\boldsymbol{\theta})$. The corresponding p-value is 0.48 . Consequently, the null hypothesis of homogeneity can not be rejected, and moving from MG to PMG estimation is appropriate.

\footnotetext{
${ }^{7}$ Estimation was carried out by using a properly modified version of the GAUSS program provided by Professor M.H. Pesaran at the webpage http://www.econ.cam.ac.uk/faculty/pesaran/.
} 


\subsection{Possible extensions and sensitivity analysis}

In what follows, we shall discuss possible extensions based on the PMG approach.

In Table A7, we provide some evidence on the differences in the marginal propensities to consume out of net financial wealth across countries. In the first econometric specification, the long-run marginal propensity to consume out of real wealth is restricted to be the same across groups, while the marginal propensity to consume out of net financial wealth is unconstrained. Formally, the long-run homogeneity assumption in (6) holds for real wealth, i.e.,

$$
\boldsymbol{\theta}_{i}^{(R W)}=\boldsymbol{\theta}^{(R W)}(\forall i)
$$

The point estimate of the marginal propensity to consume out of real wealth is 0.0013 for all countries (0.52 cents per euro, on annual basis), and it is statistically significant. On the other hand, as expected, the marginal propensity to consume out of net financial wealth varies considerably across countries. It is negative for Austria (-0.0134) and Germany (-0.0055), although it is not statistically significant at $5 \%$ for this latter. It is positive in all the other cases. In particular, it is 0.0129 for Belgium, 0.0106 for France, 0.0206 for Italy, 0.0349 for Spain, 0.0142 for USA, 0.0047 for UK. For France, the estimates are not significant, while for the UK they are significant at $10 \%$ level. Dealing with quarterly data, these point estimates have to be multiplied by 4 to get corresponding propensities at an annualised basis. This means, for instance, a marginal propensity to consume out of financial wealth of 5.16 cents per euro in Belgium or, similarly, 5.68 cents per dollar in the United States.

\section{[TABLE A7 ABOUT HERE]}

Coming to the $\phi_{i}(i=1,2, \ldots, 11)$ parameters, which measure the speed of adjustment towards the long-run relationship, they are negative and significantly different from zero in all countries (except Portugal). The fastest adjustment is in the US, where it is equal to -0.6167. A non null speed of adjustment is a necessary condition for a long-run equilibrium relationship to exist between the variables. In addition, the negative sign is expected and largely consistent with theory: with a negative sign of the speed of adjustment parameter, the variables exhibit a return to long-run equilibrium. The estimates seem to be overall plausible, economically and econometrically speaking. Finally, the adjusted $R^{2}$ is rather good for most of the countries, with two notable exceptions (Spain and Portugal).

In Table A8, we present additional results based on the PMG estimator. Differently from Table A7, in the second econometric specification the long-run marginal propensity to consume out of net financial wealth is constrained to be the identical across countries, while the marginal propensity to consume out of real wealth is kept unrestricted. Formally, the long-run homogeneity assumption in (6) holds for net financial wealth, i.e.,

$$
\boldsymbol{\theta}_{i}^{(F W)}=\boldsymbol{\theta}^{(F W)}(\forall i)
$$

\section{[TABLE A8 ABOUT HERE]}

The estimate of the marginal propensity to consume from net financial wealth is statistically significant and equal to 0.0071 . This means that, if restricted to be homogeneous, the annualised point estimate 
is 2.84 cents per additional euro of wealth. Concerning the marginal propensity to consume from real wealth, there is a considerable amount of variation found between the countries. As it can be seen, the estimates are positive and significant for four countries over eleven: Belgium (0.0176), Finland (0.0227), Italy (0.0142) and UK (0.0167). For Germany, we get a negative value, -0.0168, significant at conventional level. Furthermore, the estimates are positive but not significant for Austria, Netherlands and Spain; negative but not significantly different from zero for France, Portugal and USA. Turning to the speed of adjustment parameters, $\phi_{i}(i=1,2, \ldots, 11)$, their estimates are all negative and statistically significant, except for Portugal and Spain. This is in line and fully consistent with theory. The adjusted $R^{2}$ index is overall good, with two notable exceptions (Spain and Portugal).

It is interesting to remark that it is possible to rank the PMG models whose estimates are reported in in Tables A7 and A8. Although not reported, the restricted log-likelihood for the model where net financial wealth is identical across countries is 1750.1208; the restricted log-likelihood for the model where real wealth is identical across countries is 1764.1759. The unrestricted log-likelihood (i.e., the log-likelihood of the model where all the parameters are left unconstrained) is 1788.5927 . We can rely on the likelihoodratio test statistic $\Lambda=-2\left(\log L_{0}-\log L_{1}\right)$, where $\log L_{0}$ is the log-likelihood of the restricted model and $\log L_{1}$ is the $\log$-likelihood of the unrestricted one. Note that, after having imposed restrictions, the total number of unknown parameters is reduced. Under the null hypothesis, $\Lambda$ is distributed as a chi-square with as many degrees of freedom as the number of restrictions introduced (ten, in the case under investigation). The two restricted models are compared, one by one, to the unrestricted one.

On the basis of the likelihood-ratio test, the two sets of restrictions (the marginal propensity to consume from net financial wealth and the marginal propensity to consume from real wealth are identical across countries) are strongly rejected at conventional significance levels. Yet, on the basis of the likelihood-ratio principle, the model where the real wealth is constrained to be equal across countries has to be preferred with respect to the competitive model (in which net financial wealth is constrained). Moreover, not only statistical inference but also economic reasoning and intuition may justify the preference for the specification where the long-run coefficient of real wealth is constrained (Table A7) in comparison to the specification where the long-run coefficient of financial wealth is constrained (Table A8). We argue that the heterogeneity in national financial systems - inter alia, role of banks, diffusion of quoted shares and mutual funds, importance of private pension funds and insurance companies - is more relevant than the differences in real wealth across countries.

\subsection{Is there a role for disaggregate components of financial wealth?}

Many authors looked at the effect of changes in Stock Market capitalization as a determinant of household consumption dynamics. The idea is that mainly capital gains affect consumption, and therefore there is no need to take into account all the household financial wealth. In this Subsection we test a closely related hypothesis: specifically, we investigate whether estimation of the wealth effects, when based on a subset of total financial wealth, delivers the same results than when all the financial assets are used.

In this exercise, we only consider those financial instruments that are linked to the behavior of the Stock Exchange. We refer to three instruments: quoted shares, mutual fund units, and insurance technical reserves. ${ }^{8}$ Conventionally, we term the sum of these three instruments "equity wealth". Conversely, we

\footnotetext{
${ }^{8}$ We are conscious that in some European countries insurance companies and pension funds have a more
} 
do not include in the regression deposits and securities other than shares, which are often labelled as "safe assets", being mainly fixed in nominal terms.

Table A9 presents estimation results based on a specification in which the ratio of consumption to income is regressed on real assets (net of financial liabilities), i.e. RW-liab., and a subset of financial assets, namely the sum of quoted shares, mutual funds and insurance technical reserves, i.e. $\mathrm{SH}+\mathrm{MF}+\mathrm{ITR}$. In the error correction part, we keep all the long-run coefficients constrained to be identical across countries.

\section{[TABLE A9 ABOUT HERE]}

A quick glance at Table A9 reveals that the marginal propensity to consume from real wealth (net of financial liabilities) is 5.24 cents per additional euro of wealth, once annualised. On the other hand, the marginal propensity to consume from the financial aggregate which compounds quoted shares, mutual funds and insurance technical reserves is equal to 1.12 cents per euro of increased wealth. Both estimates are statistically significant at conventional level of $5 \%$. Furthermore, the adjustment coefficients are negative and statistically different from zero, except Portugal.

In summary, the effect of real wealth net of financial liabilities on consumption is more pronounced with respect to previous estimations. According to results in Table A9, the marginal propensity to consume out of equity wealth (i.e., the sum of quoted shares, mutual funds and insurance technical reserves) is lower than the marginal propensity to consume out of net financial assets. Expressed differently, by using the sum of three disaggregate components of total financial assets, the marginal propensity to consume is substantially reduced. Specifically, the marginal propensity to consume from equity wealth is roughly one quarter the marginal propensity to consume from net financial wealth as a whole.

This result dovetails nicely with common wisdom and economic theory: as highlighted by Altissimo et al. (2005), indeed, richer households, having relatively higher saving propensities, hold the largest amount of equity wealth. Many authors underlined that distributional issues among households matter in the econometric estimation of the wealth effect.

\section{Concluding remarks}

In this paper we estimate the effect of household net financial assets and real wealth on consumption. The dataset includes eleven OECD countries and the data run from the last quarter of 1997 to the first quarter of 2008. According to panel unit root test results, all series investigated are difference stationary. Moreover, the series in the panel are found to be cointegrated. Therefore, we adopt a pooled estimation approach to make inference about the long-run relationships among consumption, net financial and real wealth, all expressed as a ratio to income. Our conclusions may be summarised as follows.

First, dynamic panel data regressions show that net financial assets and real wealth positively influence household consumption. The estimate of the propensity to consume from net financial wealth is larger than the propensity to consume from real wealth. According to the different estimation techniques, the

conservative behavior than the American intermediaries. Therefore, the portfolios of insurance companies and pension funds are often characterized by the presence of safe assets, such as General Government securities. The same is true for mutual funds, whose portfolios include also securities other shares. 
marginal propensity to consume out of net financial wealth is around 2.5-5 cents per euro, while the marginal propensity to consume out of real wealth is between 0.5 and 2.5 cents per euro of additional wealth. As a useful summary of the estimation results presented in the paper, Table A10 presents estimates of the marginal propensity to consume out of real and financial wealth obtained by applying different specifications and estimation techniques.

\section{[TABLE A10 ABOUT HERE]}

Second, looking at individual countries results, the coefficients of financial and real assets are positive and statistically significant in the majority of cases. Furthermore, constraining the marginal propensity to consume out of real wealth to be identical across countries and leaving the marginal propensity to consume out of net financial wealth unrestricted, the effect of net financial wealth is greater than that of real wealth in Belgium, Italy, Spain, and the United States, while the opposite holds true in Austria, Finland, France, Germany, the Netherlands, Portugal and the United Kingdom.

Third, in analysing the effect of net financial wealth on consumption, we do not find a strong split between countries where mortgage equity withdrawal exists (typically the US and the UK) and other systems where this financial innovation is scarce or absent (typically the euro area countries). This evidence would support the idea that contamination of characteristics of different financial systems does not allow anymore to draw net distinctions between Anglo-Saxon financial systems and more traditional bank-oriented financial structures.

Fourth, the marginal propensity to consume from a subset of net financial wealth, namely quoted shares, mutual funds and insurance technical reserves is lower than the marginal propensity to consume out of the whole net financial wealth. This is probably linked to the fact that in most of the countries mainly the richest households partecipate in the financial markets.

Finally, in most of the cases examined the speed of adjustment parameter is negative and significantly different from zero; furthermore, the point estimates are in general high, supporting the evidence of cointegration among the variables.

We plan to extend our research to other factors often selected as co-determinants of aggregate consumption, such as demographic structure, distributional measures, interest rates, unemployment.

\section{Acknowledgements}

We would like to thank Marco Magnani and Giovanni Mastrobuoni for reading the paper and for valuable comments. For offering insights into this work, special thanks go to Piero Catte, Andrea Mercatanti and Franco Peracchi. We are also grateful to partecipants at the 57th International Statistical Institute Conference, Durban, South Africa (16-22 August 2009) and at the 50th Riunione Scientifica Annuale della Società Italiana degli Economisti, Rome, (22-24 October 2009) for helpful suggestions. We thank Michael Andreasch (Austrian Nationalbank), Matti Okko (Bank of Finland), Francesco Zollino (Bank of Italy), Ana Margarida Almeida (Bank of Portugal) and Pedro Abad Fernandez-Canaveral (Bank of Spain) for making the household dwellings data available to us. Thanks to Massimo Coletta, Giovanni Di Iasio and Luigi Infante for helping us with the dataset. The paper is the responsibility of its authors and the opinions expressed here do not necessarily reflect those of the Bank of Italy. 


\section{References}

[1] Altissimo F., Georgiou E., Sastre T., Valderrama M.T., Sterne G., Stocker M., Weth M., Whelan K. and A. Willman (2005). Wealth and asset price effects on economic activity. ECB, Occasional Paper Series, n. 29, June.

[2] Bartiloro L., Coletta M. and R. De Bonis (2008). Italian household wealth in a cross-country perspective. In Bank of Italy, Household wealth in Italy. Papers presented at the conference held in Perugia, 16-17 October 2007.

[3] Bassanetti A. and F. Zollino (2007). Aggregate consumption and housing wealth. Bank of Italy, Research Department, mimeo.

[4] Bertaut C.C. (2002). Equity prices, household wealth, and consumption growth in foreign industrial countries: Wealth effects in the 1990s. Board of Governors of the Federal Reserve System, International Finance Discussion Papers, n. 724 .

[5] Breitung J. (2000). The local power of some unit root tests for panel data. In B. Baltagi (ed.), Advances in Econometrics 15: Nonstationary Panels, Panel Cointegration, and Dynamic Panels. Amsterdam: JAI Press.

[6] Byrne J.P. and E.P. Davis (2003). Disaggregate wealth and aggregate consumption: An investigation of empirical relationships for the G7. Oxford Bulletin of Economics and Statistics, 65, 197-220.

[7] Cardoso F., Farinha L. and R. Lameira (2008). Household wealth in Portugal: revised series. Banco de Portugal, Occasional Paper Series, n. 1, September.

[8] Carrol C.D., Otsuka M. and J. Slacalek (2006). How large is the housing wealth effect? A new approach. mimeo.

[9] Case K., Quigley J. and R. Shiller (2005). Comparing wealth effects: The stock market versus the housing market. Advances in Macroeconomics, Berkeley Electronic Press, 5: Iss. 1, Article 1. Available at: http://www.bepress.com/bejm/advances/vol5/iss1/art1

[10] Catte P., Girouard N., Price R. and C. André (2004). Housing markets, wealth and the business cycle. OECD Economics Department Working Papers, n. 394.

[11] Davidson J.E.H., Hendry D.F, F. Srba and S. Yeo (1978). Econometric modelling of the aggregate timeseries relationship between consumers' expenditure and income in the United Kingdom. Economic Journal, $88,661-692$.

[12] Dreger C. and H.E. Reimers (2006). Consumption and disposable income in the EU countries: The role of wealth effects. Empirica, 33, 245-254.

[13] Dreger C. and H.E. Reimers (2009). The role of asset markets for private consumption. Evidence from panel econometric models. mimeo.

[14] Engle R.F. and C.W.J. Granger (1987). Co-integration and error correction: Representation, estimation, and testing. Econometrica, 55, 251-276.

[15] European Central Bank (2009). Housing Wealth and Private Consumption in the Euro Area. Monthly Bulletin, January, 59-71.

[16] Friedman M. (1957). A Theory of the Consumption Function. Princeton: Princeton University Press.

[17] Guiso L., Paiella M. and I. Visco (2005). Do capital gains affect consumption? Estimates of wealth effects from Italian households' behavior. Temi di discussione (Economic working papers) 555, Bank of Italy, Economic Research Department.

[18] Hadri K. and R. Larsson (2005). Testing for stationarity in heterogeneous panel data where the time dimension is finite. Econometrics Journal, 8, 55-69. 
[19] Hamburg B., Hoffman M. and J. Keller (2008). Consumption, wealth and business cycles in Germany. Empirical Economics, 34, 451-476.

[20] Kao C. (1999). Spurious regression and residual-based tests for cointegration in panel data. Journal of Econometrics, 90, 1-44.

[21] Im K.S., Pesaran M.H. and Y. Shin (2003). Testing for unit roots in heterogenous panels. Journal of Econometrics, 115, 53-74.

[22] Labhard V., Sterne G. and C. Young (2005). Wealth and consumption: An assessment of the international evidence. Bank of England, Working Paper n. 275, October.

[23] Levin A. and C.F. Lin (1993). Unit root tests in panel data: New results. Department of Economics, UC-San Diego.

[24] Levin A., Lin C.F. and C. Chu (2002). Unit root tests in panel data: asymptotic and finite-sample properties. Journal of Econometrics, 108, 1-24.

[25] Lettau M. and S. Ludvigson (2001). Consumption, aggregate wealth, and expected stock returns. The Journal of Finance, no.3, 815-849.

[26] Lettau M. and S. Ludvigson (2004). Understanding trend and cycle in asset values: Reevaluating the wealth effect on consumption. American Economic Review, 94, 276-299.

[27] Maddala G.S. and S. Wu (1999). A comparative study of unit root tests with panel data and a new simple test. Oxford Bulletin of Economics and Statistics, Special Issue, 631-652.

[28] Modigliani F. (1975). The Life Cycle Hypothesis of Saving Twenty Years Later. In M. Parkin and A. R. Nobay (eds.), Contemporary Issues in Economics. Manchester: Manchester University Press.

[29] Morris A.D. and M.G. Palumbo (2001). A primer on the economics and time series econometrics of wealth effects. Finance and Economics Discussion Series 2001-09, Board of Governors of the Federal Reserve System (U.S.).

[30] Paiella M. (2004). Does wealth affect consumption? Evidence for Italy. Temi di discussione (Economic working papers) 510, Bank of Italy, Economic Research Department.

[31] Pedroni P. (2000). Fully modified OLS for heterogeneous cointegrated panles. Advances in Econometrics 15: Nonstationary Panels, Panel Cointegration, and Dynamic Panels. Amsterdam: JAI Press.

[32] Pesaran M.H. and Y. Shin (1997). An autoregressive distributed lag modelling approach to cointegration analysis. In S. Strom (ed.), Econometrics and Economic Theory in the 20th Century: The Ragnar Frisch Centennial Symposium. Cambridge: Cambridge University Press.

[33] Pesaran M.H., Shin Y. and R.P. Smith (1999). Pooled mean group estimation of dynamic heterogeneous panels. Journal of the American Statistical Association, 94, 621-634.

[34] Pesaran M.H. and R.P. Smith (1995). Estimating long-run relationships from dynamic heterogeneous panels. Journal of Econometrics, 68, 79-113.

[35] Pichette L. and D. Tremblay (2003). Are wealth effects important for Canada? Bank of Canada Working Paper, n. 30.

[36] Poterba J.M. (2000). Stock market wealth and consumption. Journal of Economic Perspectives, 14, 99-118.

[37] Salotti S. (2008). The determinants of household savings: Is there a role for wealth? Università degli Studi di Siena, mimeo.

[38] Slacalek J. (2006). What drives personal consumption? The role of housing and financial wealth. German Institute for Economic Research, Berlin.

[39] Tang K.K. (2006). The wealth effect of housing on aggregate consumption. Applied Economics Letters, 13, 189-193. 


\section{Appendix}

\section{Tables and figures}

Table A1: Panel Unit Root Tests

\begin{tabular}{lcc}
\hline Unit Root Test & test statistic & p-value \\
& & \\
& \\
& Consumption over income \\
& \\
Levin-Lin-Chu (LLC) & 2.2397 & 0.9874 \\
Im-Pesaran-Shin (IPS) & 1.5739 & 0.9422 \\
Maddala-Wu (MW) & 15.1064 & 0.8576 \\
Unbiased LL (ULL) & 0.7115 & 0.7616 \\
Hadri-Larsson (HL) & 12.4628 & 0.0000 \\
\hline
\end{tabular}

Net financial wealth over income

\begin{tabular}{lcc} 
Levin-Lin-Chu (LLC) & 2.0063 & 0.9776 \\
Im-Pesaran-Shin (IPS) & 2.1695 & 0.9850 \\
Maddala-Wu (MW) & 14.3651 & 0.8880 \\
Unbiased LL (ULL) & 1.3237 & 0.9072 \\
Hadri-Larsson (HL) & 10.7929 & 0.0000 \\
\hline
\end{tabular}

Real wealth (dwellings) over income

\begin{tabular}{lcc} 
Levin-Lin-Chu (LLC) & 5.5897 & 1.0000 \\
Im-Pesaran-Shin (IPS) & 8.8461 & 1.0000 \\
Maddala-Wu (MW) & 1.7091 & 1.0000 \\
Unbiased LL (ULL) & 5.0545 & 1.0000 \\
Hadri-Larsson (HL) & 18.8950 & 0.0000 \\
\hline
\end{tabular}

Tests LLC, IPS and ULL are left-sided, while MW and HL are rightsided tests. All p-values are reported such that: $\mathrm{H}_{0}$ is rejected if $\mathrm{p}$-value $<0.05$. For all the series the sample goes from 1997Q4 until 2008Q1. 
Table A2: Panel Cointegration Test Results and Cointegration Estimates

\section{Group-mean Panel Dynamic OLS}

$\begin{array}{lccc} & \text { coefficient } & \text { test statistic } & \text { p-value } \\ \text { FW } & 0.0108 & 6.4475 & 0.0000 \\ \text { RW } & 0.0108 & 14.0023 & 0.0000\end{array}$

The Panel Cointegration Test(Homogeneous): Kao (1999)

$\begin{array}{lll}D F_{\rho} \text { Test } & -38.7577 & \text { Prob: } 0.0000 \\ D F_{t} \text { Test } & -18.4880 & \text { Prob: } 0.0000 \\ D F_{\rho}^{*} \text { Test } & -12.6275 & \text { Prob: } 0.0000 \\ D F_{t}^{*} \text { Test } & -13.1376 & \text { Prob: } 0.0000\end{array}$

The ADF Panel Cointegration Test(Homogeneous): Kao (1999)

\begin{tabular}{ccc} 
lags & ADF test statistic & prob: \\
1 & -6.3498 & 0.0000 \\
\hline
\end{tabular}

Outcome of the Kao (1999) test. FW is the coefficient of net financial wealth, RW is the coefficient of real wealth. Null hypothesis $\left(\mathrm{H}_{0}\right)$ : the estimated equation is not cointegrated. All p-values are reported such that: $\mathrm{H}_{0}$ is rejected if $\mathrm{p}$-value $<0.05$. For all the series the sample goes from 1997Q4 until 2008Q1.

Table A3: Preliminary evidence based on static Fixed Effects Static Fixed Effects Estimates

\begin{tabular}{lccccc}
\hline & Coef. & St. Er. & t-ratio & Robust St. Er. & t-ratio \\
MPC (RW) & 0.0008 & 0.0004 & 2.1869 & 0.0008 & 1.0218 \\
MPC (FW) & 0.0071 & 0.0015 & 4.8128 & 0.0062 & 1.1473 \\
trend & 0.0008 & 0.0001 & 6.5560 & 0.0005 & 1.6901 \\
& \multicolumn{5}{c}{} \\
& \multicolumn{5}{c}{ Summary statistics and regression diagnostics } \\
& LL & SIGMA & AIC & SC & \\
& 1075.89 & 0.023 & 1061.89 & 1033.11 & \\
& & & & &
\end{tabular}

LL stands for log-likelihood of the model, RBARSQ for Adjusted Rsquared, SIGMA for S.E. of regression, AIC for Akaike information criterion, while SC for Schwarz criterion. For all the series the sample goes from 1997Q4 until 2008Q1. 
Table A4: Autoregressive Distributed Lag specification

\begin{tabular}{lccc}
\hline Country & Consumption & Net financial Wealth & Real wealth \\
& & & \\
\hline & 2 & 2 & 2 \\
Austria & 2 & 2 & 0 \\
Belgium & 1 & 1 & 0 \\
Finland & 1 & 1 & 2 \\
France & 1 & 1 & 0 \\
Germany & 1 & 0 & 0 \\
Italy & 1 & 0 & 0 \\
Netherlands & 2 & 0 & 0 \\
Portugal & 0 & 0 & 0 \\
Spain & 1 & 1 & 0 \\
US & 1 & 1 & \\
UK & & & \\
\end{tabular}

Orders of lags in the ARDL model which are selected by the Schwarz Information Criterion. For all the series the sample goes from 1997Q4 until 2008Q1. 
Table A5: Pooled Mean Group (PMG) estimates of the long-run parameters: RW and FW constrained

\begin{tabular}{|c|c|c|c|c|c|c|}
\hline \multirow[t]{2}{*}{ Country } & \multicolumn{3}{|c|}{ Estimates } & \multicolumn{3}{|c|}{ Diagnostic Statistics } \\
\hline & $\phi$ & RW & FW & SIGMA & RBARSQ & LL \\
\hline Austria & $\begin{array}{c}-0.164 \\
(0.086)\end{array}$ & $\begin{array}{c}0.006 \\
(0.002)\end{array}$ & $\begin{array}{c}0.011 \\
(0.002)\end{array}$ & 0.004 & 0.26 & 173.20 \\
\hline Belgium & $\begin{array}{l}-0.418 \\
(0.101)\end{array}$ & $\begin{array}{c}0.006 \\
(0.002)\end{array}$ & $\begin{array}{c}0.011 \\
(0.002)\end{array}$ & 0.006 & 0.58 & 155.62 \\
\hline Finland & $\begin{array}{l}-0.223 \\
(0.067)\end{array}$ & $\begin{array}{c}0.006 \\
(0.002)\end{array}$ & $\begin{array}{c}0.011 \\
(0.002)\end{array}$ & 0.006 & 0.51 & 152.26 \\
\hline France & $\begin{array}{l}-0.324 \\
(0.088)\end{array}$ & $\begin{array}{c}0.006 \\
(0.002)\end{array}$ & $\begin{array}{c}0.011 \\
(0.002)\end{array}$ & 0.004 & 0.68 & 166.48 \\
\hline Germany & $\begin{array}{l}-0.169 \\
(0.086)\end{array}$ & $\begin{array}{c}0.006 \\
(0.002)\end{array}$ & $\begin{array}{c}0.011 \\
(0.002)\end{array}$ & 0.004 & 0.12 & 172.95 \\
\hline Italy & $\begin{array}{l}-0.316 \\
(0.066)\end{array}$ & $\begin{array}{c}0.006 \\
(0.002)\end{array}$ & $\begin{array}{c}0.011 \\
(0.002)\end{array}$ & 0.005 & 0.31 & 161.76 \\
\hline Netherlands & $\begin{array}{c}-0.196 \\
(0.081)\end{array}$ & $\begin{array}{c}0.006 \\
(0.002)\end{array}$ & $\begin{array}{c}0.011 \\
(0.002)\end{array}$ & 0.007 & 0.07 & 148.84 \\
\hline Portugal & $\begin{array}{c}0.007 \\
(0.074)\end{array}$ & $\begin{array}{c}0.006 \\
(0.002)\end{array}$ & $\begin{array}{c}0.011 \\
(0.002)\end{array}$ & 0.006 & 0.03 & 153.77 \\
\hline Spain & $\begin{array}{c}-1.000 \\
(\mathrm{NA})\end{array}$ & $\begin{array}{c}0.006 \\
(0.002)\end{array}$ & $\begin{array}{c}0.011 \\
(0.002)\end{array}$ & 0.017 & -11.07 & 108.88 \\
\hline USA & $\begin{array}{c}-0.644 \\
(0.122)\end{array}$ & $\begin{array}{c}0.006 \\
(0.002)\end{array}$ & $\begin{array}{c}0.011 \\
(0.002)\end{array}$ & 0.006 & 0.57 & 153.40 \\
\hline UK & $\begin{array}{l}-0.405 \\
(0.113)\end{array}$ & $\begin{array}{c}0.006 \\
(0.002)\end{array}$ & $\begin{array}{c}0.011 \\
(0.002)\end{array}$ & 0.007 & 0.46 & 145.77 \\
\hline
\end{tabular}

Group-specific estimates of the long-run coefficients based on ARDL specifications selected using the Schwarz Criterion. Estimation is conducted by pooled maximum likelihood, i.e., by concentrating the pooled maximum likelihood, under the assumption that the innovations are normally distributed. Figures in brackets are the standard errors of the coefficients. LL stands for log-likelihood of the model, RBARSQ for Adjusted R-squared, SIGMA for S.E. of regression. For all the series the sample goes from 1997Q4 until 2008Q1. 
Table A6: Mean Group (MG) estimates of the long-run and short-run parameters

\begin{tabular}{|c|c|c|c|}
\hline \multicolumn{4}{|c|}{ MG Estimates of the pooled parameters } \\
\hline Variable & Coef. & St. Er. & t-ratio \\
\hline \multicolumn{4}{|c|}{ Long-Run Coefficients Restricted Across Countries } \\
\hline RW & 0.0013 & 0.0005 & 2.866 \\
\hline \multicolumn{4}{|c|}{ Unrestricted Long-Run Coefficients } \\
\hline FW & 0.0117 & 0.0052 & 2.240 \\
\hline \multicolumn{4}{|c|}{ Error Correction Coefficients } \\
\hline$\phi$ & -0.3951 & 0.0777 & -5.087 \\
\hline \multicolumn{4}{|c|}{ Short-Run Coefficients } \\
\hline RW & 0.0010 & 0.0002 & 5.0870 \\
\hline FW & 0.0050 & 0.0033 & 1.5320 \\
\hline$\Delta \mathrm{C}(-1)$ & 0.0280 & 0.0487 & 0.5750 \\
\hline$\Delta \mathrm{RW}$ & 0.0410 & 0.0200 & 2.0670 \\
\hline$\Delta \mathrm{RW}(-1)$ & -0.0030 & 0.0027 & -1.1230 \\
\hline$\Delta \mathrm{FW}$ & 0.0002 & 0.0027 & 0.0720 \\
\hline$\Delta \mathrm{FW}(-1)$ & -0.0002 & 0.0020 & -0.0980 \\
\hline trend & 0.0001 & $6.8 \mathrm{e}-05$ & 1.4740 \\
\hline constant & 0.3090 & 0.0556 & 5.4740 \\
\hline
\end{tabular}

The group-specific estimates of the long-run coefficients, on which MG estimates are based, are obtained starting from ARDL specifications selected using the Schwarz Criterion. For all the series the sample goes from 1997Q4 until 2008Q1. 
Table A7: Pooled Mean Group (PMG) estimates of the long-run parameters: RW constrained, FW unconstrained

\begin{tabular}{|c|c|c|c|c|c|c|}
\hline \multirow[t]{2}{*}{ Country } & \multicolumn{3}{|l|}{ Estimates } & \multicolumn{3}{|c|}{ Diagnostic Statistics } \\
\hline & $\phi$ & RW & FW & SIGMA & RBARSQ & $\mathrm{LL}$ \\
\hline Austria & $\begin{array}{l}-0.3950 \\
(0.1046)\end{array}$ & $\begin{array}{c}0.0013 \\
(0.0005)\end{array}$ & $\begin{array}{c}-0.0134 \\
(0.0052)\end{array}$ & 0.003 & 0.427 & 178.25 \\
\hline Belgium & $\begin{array}{l}-0.4012 \\
(0.0916)\end{array}$ & $\begin{array}{c}0.0013 \\
(0.0005)\end{array}$ & $\begin{array}{c}0.0129 \\
(0.0032)\end{array}$ & 0.005 & 0.592 & 156.21 \\
\hline Finland & $\begin{array}{c}-0.1768 \\
(0.0607)\end{array}$ & $\begin{array}{c}0.0013 \\
(0.0005)\end{array}$ & $\begin{array}{c}0.0004 \\
(0.0134)\end{array}$ & 0.006 & 0.499 & 151.85 \\
\hline France & $\begin{array}{c}-0.4017 \\
(0.0954)\end{array}$ & $\begin{array}{c}0.0013 \\
(0.0005)\end{array}$ & $\begin{array}{c}0.0106 \\
(0.0086)\end{array}$ & 0.004 & 0.712 & 168.35 \\
\hline Germany & $\begin{array}{c}-0.4789 \\
(0.1158)\end{array}$ & $\begin{array}{c}0.0013 \\
(0.0005)\end{array}$ & $\begin{array}{c}-0.0055 \\
(0.0034)\end{array}$ & 0.003 & 0.324 & 178.21 \\
\hline Italy & $\begin{array}{c}-0.3135 \\
(0.0932)\end{array}$ & $\begin{array}{c}0.0013 \\
(0.0005)\end{array}$ & $\begin{array}{c}0.0206 \\
(0.0083)\end{array}$ & 0.006 & 0.138 & 157.14 \\
\hline Netherlands & $\begin{array}{c}-0.2004 \\
(0.0827)\end{array}$ & $\begin{array}{c}0.0013 \\
(0.0005)\end{array}$ & $\begin{array}{c}0.0030 \\
(0.0043)\end{array}$ & 0.007 & 0.066 & 148.79 \\
\hline Portugal & $\begin{array}{c}-0.0116 \\
(0.0840)\end{array}$ & $\begin{array}{c}0.0013 \\
(0.0005)\end{array}$ & $\begin{array}{c}0.0462 \\
(0.3305)\end{array}$ & 0.006 & 0.030 & 153.77 \\
\hline Spain & $\begin{array}{c}-1.0000 \\
(\mathrm{NA})\end{array}$ & $\begin{array}{c}0.0013 \\
(0.0005)\end{array}$ & $\begin{array}{c}0.0349 \\
(0.0036)\end{array}$ & 0.004 & 0.495 & 172.36 \\
\hline USA & $\begin{array}{c}-0.6167 \\
(0.1179)\end{array}$ & $\begin{array}{c}0.0013 \\
(0.0005)\end{array}$ & $\begin{array}{c}0.0142 \\
(0.0046)\end{array}$ & 0.006 & 0.603 & 155.25 \\
\hline UK & $\begin{array}{c}-0.3499 \\
(0.1163)\end{array}$ & $\begin{array}{c}0.0013 \\
(0.0005)\end{array}$ & $\begin{array}{c}0.0047 \\
(0.0028)\end{array}$ & 0.008 & 0.408 & 143.98 \\
\hline
\end{tabular}

Group-Specific Estimates of the Long-Run Coefficients Based on ARDL Specifications Selected Using the Schwarz Criterion. Estimation is conducted by pooled maximum likelihood, i.e., by concentrating the pooled maximum likelihood, under the assumption that the innovations are normally distributed. Figures in brackets are the standard errors of the coefficients. LL stands for log-likelihood of the model, RBARSQ for Adjusted R-squared, SIGMA for S.E. of regression. For all the series the sample goes from 1997Q4 until 2008Q1. 
Table A8: Pooled Mean Group (PMG) estimates of the long-run parameters: RW unconstrained, FW constrained

\begin{tabular}{|c|c|c|c|c|c|c|}
\hline \multirow[t]{2}{*}{ Country } & \multicolumn{3}{|l|}{ Estimates } & \multicolumn{3}{|c|}{ Diagnostic Statistics } \\
\hline & $\phi$ & RW & FW & SIGMA & RBARSQ & $\mathrm{LL}$ \\
\hline Austria & $\begin{array}{l}-0.1852 \\
(0.0960)\end{array}$ & $\begin{array}{c}0.0023 \\
(0.0106)\end{array}$ & $\begin{array}{c}0.0071 \\
(0.0016)\end{array}$ & 0.004 & 0.265 & 173.27 \\
\hline Belgium & $\begin{array}{c}-0.4749 \\
(0.1086)\end{array}$ & $\begin{array}{c}0.0176 \\
(0.0075)\end{array}$ & $\begin{array}{c}0.0071 \\
(0.0016)\end{array}$ & 0.005 & 0.597 & 156.44 \\
\hline Finland & $\begin{array}{c}-0.2701 \\
(0.0880)\end{array}$ & $\begin{array}{c}0.0227 \\
(0.0121)\end{array}$ & $\begin{array}{c}0.0071 \\
(0.0016)\end{array}$ & 0.006 & 0.516 & 152.54 \\
\hline France & $\begin{array}{c}-0.3949 \\
(0.0900)\end{array}$ & $\begin{array}{l}-0.0046 \\
(0.0067)\end{array}$ & $\begin{array}{c}0.0071 \\
(0.0016)\end{array}$ & 0.004 & 0.717 & 168.67 \\
\hline Germany & $\begin{array}{c}-0.3609 \\
(0.0959)\end{array}$ & $\begin{array}{c}-0.0168 \\
(0.0070)\end{array}$ & $\begin{array}{c}0.0071 \\
(0.0016)\end{array}$ & 0.003 & 0.309 & 177.80 \\
\hline Italy & $\begin{array}{c}-0.2868 \\
(0.0732)\end{array}$ & $\begin{array}{c}0.0142 \\
(0.0044)\end{array}$ & $\begin{array}{c}0.0071 \\
(0.0016)\end{array}$ & 0.005 & 0.328 & 162.26 \\
\hline Netherlands & $\begin{array}{c}-0.1922 \\
(0.0778)\end{array}$ & $\begin{array}{c}0.0578 \\
(0.0421)\end{array}$ & $\begin{array}{c}0.0071 \\
(0.0016)\end{array}$ & 0.007 & 0.093 & 149.40 \\
\hline Portugal & $\begin{array}{c}-0.0543 \\
(0.0757)\end{array}$ & $\begin{array}{c}-0.2964 \\
(0.3990)\end{array}$ & $\begin{array}{c}0.0071 \\
(0.0016)\end{array}$ & 0.005 & 0.135 & 156.06 \\
\hline Spain & $\begin{array}{c}-1.000 \\
(\mathrm{NA})\end{array}$ & $\begin{array}{c}0.0004 \\
(0.0007)\end{array}$ & $\begin{array}{c}0.0071 \\
(0.0016)\end{array}$ & 0.006 & -0.259 & 154.08 \\
\hline USA & $\begin{array}{c}-0.6547 \\
(0.1203)\end{array}$ & $\begin{array}{c}-0.0018 \\
(0.0238)\end{array}$ & $\begin{array}{c}0.0071 \\
(0.0016)\end{array}$ & 0.006 & 0.576 & 153.88 \\
\hline UK & $\begin{array}{c}-0.3701 \\
(0.1072)\end{array}$ & $\begin{array}{c}0.0167 \\
(0.0073)\end{array}$ & $\begin{array}{c}0.0071 \\
(0.0016)\end{array}$ & 0.007 & 0.455 & 145.70 \\
\hline
\end{tabular}

Group-Specific Estimates of the Long-Run Coefficients Based on ARDL Specifications Selected Using the Schwarz Criterion. Estimation is conducted by pooled maximum likelihood, i.e., by concentrating the pooled maximum likelihood, under the assumption that the innovations are normally distributed. Figures in brackets are the standard errors of the coefficients. LL stands for log-likelihood of the model, RBARSQ for Adjusted R-squared, SIGMA for S.E. of regression. For all the series the sample goes from 1997Q4 until 2008Q1. 
Table A9: Pooled Mean Group (PMG) estimates of the long-run parameters: RW-liab. and $\mathrm{SH}+\mathrm{MF}+\mathrm{ITR}$ constrained

\begin{tabular}{|c|c|c|c|c|c|c|}
\hline \multirow[t]{2}{*}{ Country } & \multicolumn{3}{|l|}{ Estimates } & \multicolumn{3}{|c|}{ Diagnostic Statistics } \\
\hline & $\phi$ & RW-liab. & $\mathrm{SH}+\mathrm{MF}+\mathrm{ITR}$ & SIGMA & RBARSQ & LL \\
\hline Austria & $\begin{array}{c}-0.2488 \\
(0.0963)\end{array}$ & $\begin{array}{c}0.0131 \\
(0.0017)\end{array}$ & $\begin{array}{c}0.0028 \\
(0.0006)\end{array}$ & 0.004 & 0.191 & 170.05 \\
\hline Belgium & $\begin{array}{l}-0.3705 \\
(0.1023)\end{array}$ & $\begin{array}{c}0.0131 \\
(0.0017)\end{array}$ & $\begin{array}{c}0.0028 \\
(0.0006)\end{array}$ & 0.007 & 0.416 & 149.01 \\
\hline Finland & $\begin{array}{l}-0.2318 \\
(0.0727)\end{array}$ & $\begin{array}{c}0.0131 \\
(0.0017)\end{array}$ & $\begin{array}{c}0.0028 \\
(0.0006)\end{array}$ & 0.007 & 0.354 & 146.64 \\
\hline France & $\begin{array}{l}-0.4347 \\
(0.1071)\end{array}$ & $\begin{array}{c}0.0131 \\
(0.0017)\end{array}$ & $\begin{array}{c}0.0028 \\
(0.0006)\end{array}$ & 0.005 & 0.555 & 159.66 \\
\hline Germany & $\begin{array}{c}-0.2246 \\
(0.0881)\end{array}$ & $\begin{array}{c}0.0131 \\
(0.0017)\end{array}$ & $\begin{array}{c}0.0028 \\
(0.0006)\end{array}$ & 0.004 & 0.056 & 170.83 \\
\hline Italy & $\begin{array}{l}-0.3391 \\
(0.0730)\end{array}$ & $\begin{array}{c}0.0131 \\
(0.0017)\end{array}$ & $\begin{array}{c}0.0028 \\
(0.0006)\end{array}$ & 0.005 & 0.308 & 162.22 \\
\hline Netherlands & $\begin{array}{l}-0.237 \\
(0.063)\end{array}$ & $\begin{array}{c}0.0131 \\
(0.0017)\end{array}$ & $\begin{array}{c}0.0028 \\
(0.0006)\end{array}$ & 0.006 & 0.218 & 149.48 \\
\hline Portugal & $\begin{array}{l}-0.0403 \\
(0.0664)\end{array}$ & $\begin{array}{c}0.0131 \\
(0.0017)\end{array}$ & $\begin{array}{c}0.0028 \\
(0.0006)\end{array}$ & 0.006 & -0.010 & 156.36 \\
\hline Spain & $\begin{array}{c}-1.000 \\
(\mathrm{NA})\end{array}$ & $\begin{array}{c}0.0131 \\
(0.0017)\end{array}$ & $\begin{array}{c}0.0028 \\
(0.0006)\end{array}$ & 0.017 & -11.212 & 109.86 \\
\hline USA & $\begin{array}{c}-1.000 \\
(\mathrm{NA})\end{array}$ & $\begin{array}{c}0.0131 \\
(0.0017)\end{array}$ & $\begin{array}{c}0.0028 \\
(0.0006)\end{array}$ & 0.009 & 0.104 & 137.43 \\
\hline $\mathrm{UK}$ & $\begin{array}{c}-1.000 \\
(\mathrm{NA})\end{array}$ & $\begin{array}{c}0.0131 \\
(0.0017)\end{array}$ & $\begin{array}{c}0.0028 \\
(0.0006)\end{array}$ & 0.009 & 0.266 & 138.45 \\
\hline
\end{tabular}

Group-Specific Estimates of the Long-Run Coefficients Based on ARDL Specifications Selected Using the Schwarz Criterion. Estimation is conducted by pooled maximum likelihood, i.e., by concentrating the pooled maximum likelihood, under the assumption that the innovations are normally distributed. Figures in brackets are the standard errors of the coefficients. RW-liab. stands for real wealth minus liabilities; $\mathrm{SH}+\mathrm{MF}+\mathrm{ITR}$ represents the sum of quoted shares, mutual funds and insurance technical reserves. LL is the log-likelihood of the model, RBARSQ the Adjusted R-squared, SIGMA the S.E. of regression. For all the series the sample goes from 1997Q4 until 2008Q1.

Table A10: Summary of MPC estimates per euro of additional wealth

Marginal propensity to consume out of:

\begin{tabular}{c|c|c}
\hline Estimation method & Real Wealth (RW) & Net Financial Wealth (FW) \\
\hline Static Fixed Effects & 0.3 cents & 2.8 cents \\
PMG & 2.4 cents & 4.4 cents \\
MG & 0.5 cents & 4.7 cents \\
PMG extension (RW constrained) & 0.5 cents & 2.8 cents \\
PMG extension (FW constrained) & & SH+MF+ITR \\
\hline Estimation method & Real Wealth (net of liab.) & 1.1 cents \\
\hline PMG extension (subset of FW) & 5.2 cents &
\end{tabular}



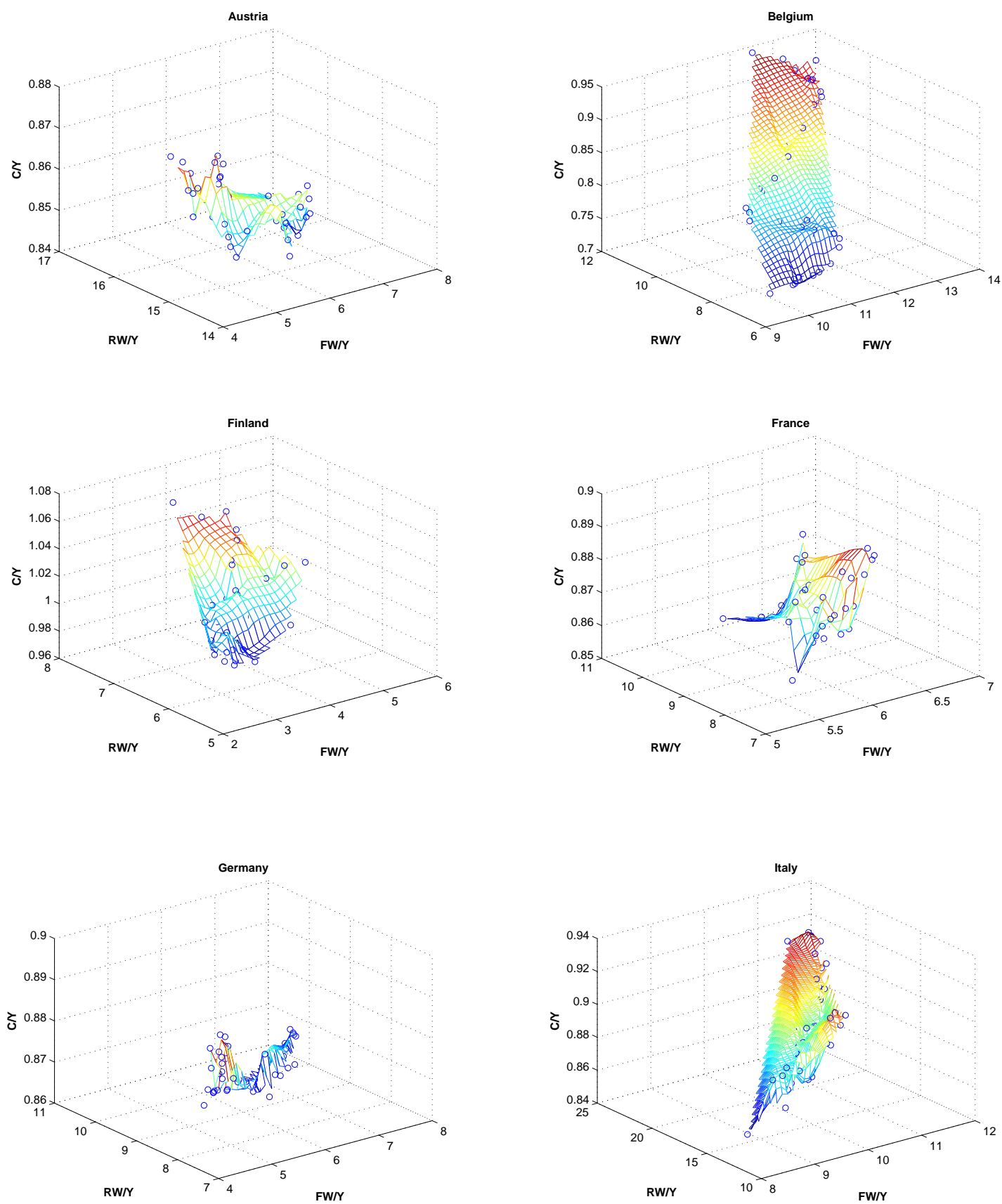

Figure A1: Three-dimensional plots using triangle-based cubic interpolation. From left to right and top to down: Austria, Belgium, Finand, France, Germany, Italy. 

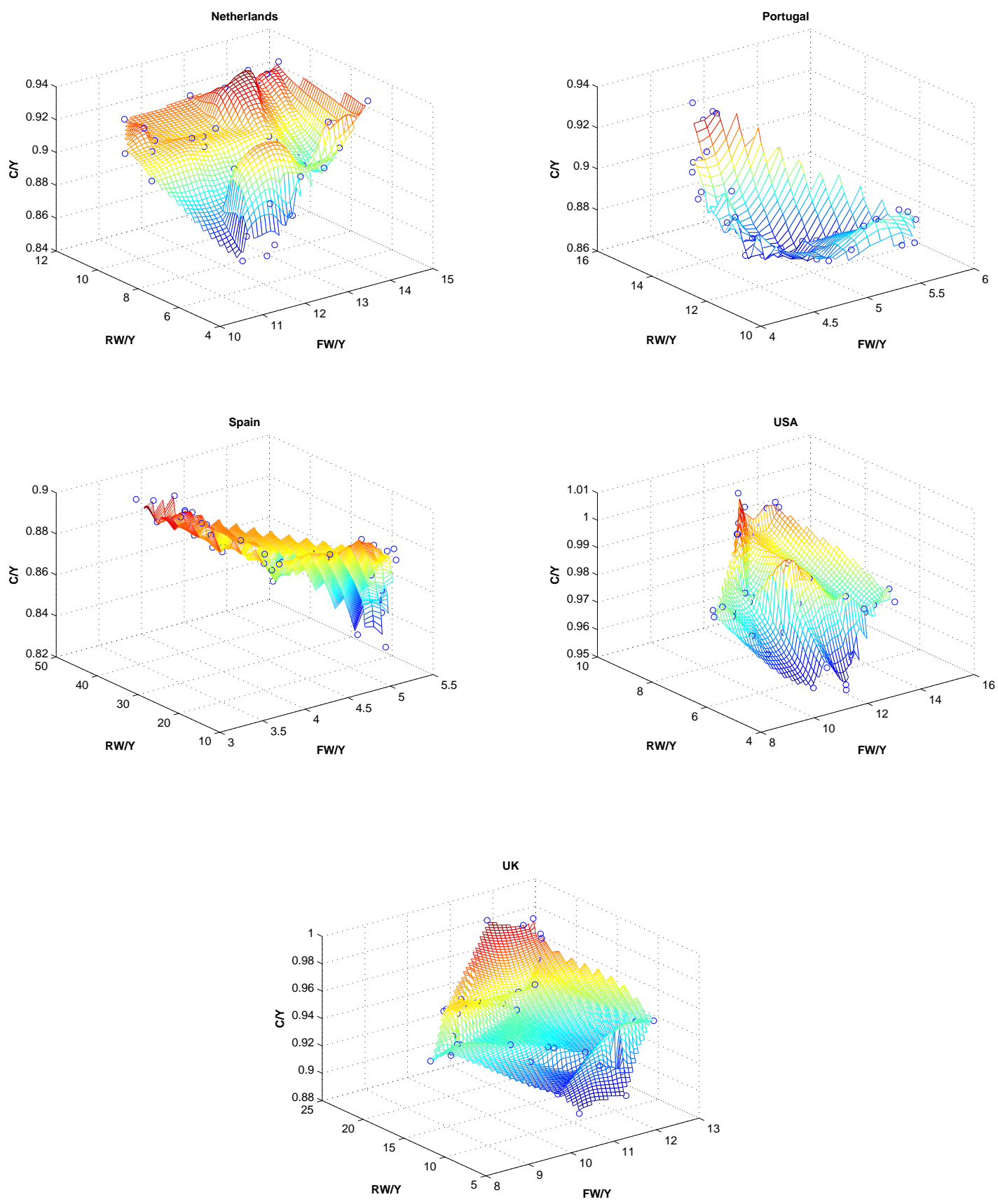

Figure A2: Three-dimensional plots using triangle-based cubic interpolation. From left to right and top to down: Netherlands, Portugal, Spain, USA, UK. 